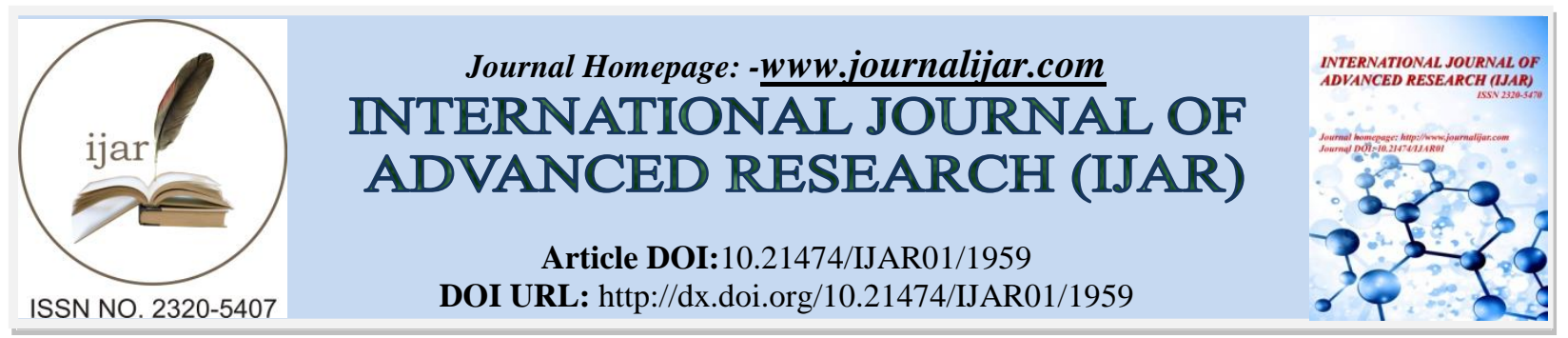

RESEARCH ARTICLE

\title{
DEPRESSION AMONG TAIBAH UNIVERSITY MEDICAL STUDENTS, ALMADINAH AL- MONAWWARAH, KSA, 2013.
} Mohammed Alnuman, Ryan Alruhaili, Abdullah Almutairi, Abdulrahman Alraddadi, Abdullah Abu-Alnasr,
Mohammed Alhusayni, Faisal Al Rwithey, Abdulaziz Al Jabri and Abdulrahman Alsaedi.

\section{Manuscript Info}

Manuscript History

Received: 21 August 2016

Final Accepted: 22 September 2016

Published: October 2016

Key words: -

Depression, medical student

\section{Abstract}

Medical field is considered stressful as it deals with human life. People expect medical care to be delivered under all circumstances which make this career a demanding one. Depression ranks as one of the major health problem today. There will be a drop in the general health of the world in coming years, if it affects the doctors.

\section{Background: -}

Depression is considered as one of the most common mental disorder, characterized by feeling of sad, losing of interest and pleasure, feelings of being guilt and low self-esteem, sleeping and appetite changes, feelings of tiredness, and inability of concentration. -2- "Depression ranks as one of the major health problems of today. Millions of patients suffering from some form of this disorder crowd the psychiatric and general hospitals, the outpatients' clinics, and the offices of private practitioners. Depression may appear as a primary disorder or it may accompany a wide variety of other psychiatric or medical disorder. Not only is depression a prominent cause of human misery but its by-product, suicide, is a leading cause of death in certain age groups" -3- There are more than 350 million people in different ages and races suffering from depression and that was for the recent update of the WHO website in 2013.-4- Going back in 2011 a result of a study about depression was done by WHO was 121 million depressed people in the whole world. -5- Focusing on medical students and the future's doctors who are going to treat the depressed patients. This mission will not be done if doctors themselves are depressed. Medical field is considered stressful as it deals with human life. People expect medical professionals to deliver under all circumstances which make this career a demanding one. -1- Many Studies have reported high rates of psychological morbidity amongst medical students for different reasons as, reduced performance, increased alcohol consumption and suicide. -14-18-

According to so many studies were done on medical students. It was found out that the results of some studies about depression among medical students were. Starting with far continents, in Ireland the total medical and 
business students was 338. 47 were depressed. According to the study, the percentage of depression was more in medical students. -6- In USA the total medical students were 450, 47 were depressed. Only 13 were reported treatment. -7- In far Asia، in India the total medical students were 336, out of 212 males 90 were depressed and 75 were depressed out of 124 females. -8- In Karnataka the total medical students were 400, 153 males were depressed while 132 females were depressed. -9- In Pakistan the total medical students were 252. 33 out of 60 males were depressed and 80 out of 169 females were depressed. -10-In Nepal the total medical students were 94, 12 out of 57 males were depressed and also 12 out of 37 females were depressed. -11- These are some studies in the kingdom of Saudi Arabia, in Al-Qaseem the total medical students were 393, 128 out of 288 males were depressed while 70 out of 105 females were depressed. -12- Another study in Al-Qaseem the total medical students were 226, in the first three years. 68 out of 149 males were depressed and 46 out of 77 females were depressed. -12- In Jeddah the total medical students were 450, 66 were depressed and 384 were normal. -13- Based on these studies, it is observed that depression is one of major disorders affecting medical students. Ignoring this disaster problem will lead to paralysis in the dynamical bump of the health care staff. So we chose them as our target population. As far as the literature review was done. It was found out that no one has done this research on the medical students of Taibah University in Almadinah Almonawarah. At the end of this research we are going to determine the prevalence of depression among medical students of Taibah University in 2013 and to identify the risk factors that affect depression among medical students in Taibah University in 2013. Our aim is to prevent and reduce the percentage of depression among medical students.

The expected hypothesis is

"There is a negative relationship between depression and going through medical levels"

And "There is a positive relationship between the included risk variables in the questionnaire and depression

\section{Subjects and methods: -}

The process of research was carried out through the following phases:

\section{I- Preparatory phase:}

During this phase, the following items were covered:

\section{A-Survey of literature:}

The review of literature was collected during the period of one month

B-Study variables: socio-demographic data (age, sex, academic year, residence, marital status, living with parents or not and work if present). Then other variables are divided into two groups. The first group is about the general risk factors that affect depression among regular people which are (Chronic diseases, Chronic medications, Smoking, Addiction to something, Major stress events, Daily stress, satisfied with traditions, satisfied with social relations, Satisfied with economic status). -20- The second group is about the specific risk factors that affect the 
depression among the medical students which are (Study years too long, Study units too much, Amount of information too much, Teachers have negative effect, accept weekly exams, Accept Exams results, History of failure in exams, satisfied with sleeping hours, Not Satisfied with marriage delay, Satisfied with your weight). -20-

\section{C- Target population:}

334 students (males and females) in medical college of Taibah University in all five years at Al-Madinah Al-Monawwara.

\section{D- Ethical considerations:}

- A formal approval was taken from the research ethical committee of the university

- Informal consent was taken from each student to participate in the research.

- The procedure and aims of the study were explained to the volunteers participating in the research.

\section{E- Pilot study:}

Before conducting the research, a pilot study was carried out on some students. Preliminary questionnaire was tested to assess the validity, reliability, applicability and timing considering that the examination tool was examined before in English and Arabic people. -21-

\section{II- Implementation phase:}

\section{A- Research strategy:}

\section{1- Study design:}

The research is a cross sectional descriptive study.

\section{2- Research setting:}

College of Medicine in Taibah University at Al-Madinah Al-Monawwara.

\section{B- Sample design}

A multistage random sample was done. A sampling frame of all students at the different years in the college of Medicine of Taibah University that is present in the university compound in Al-Madinah Al-Monawwara. Using the sample equation for the cross sectional study, assuming the prevalence of depression. some similar study results and confidence interval 99\% minimum sample size required was 334 students. 400 students were taken to compensate for missing data in the questionnaire and the response rate. So any missing data in any questionnaire was a just reason for that questionnaire to be excluded till the 334 questionnaire were checked that they were filled correctly and no missing data. A multistage proportionate sampling method was applied. For each class the students were 
chosen using a systematic random sample technique from the available registers.

\section{Inclusion criteria:}

Students in the medical college of Taibah University who agree to share in the research.

\section{Exclusion criteria:}

Students who refused to fill the questionnaires

\section{Instruments of data collection (research tools):}

Self-administered questionnaire: An anonymous self-administered questionnaire in Arabic language. The questionnaire was including questions about all the study variables mentioned before and were included in the annex. Depression Anxiety and Stress (DASS). -21-

\section{Data processing:}

- Variables were coded for proper extraction of data.

- Questionnaires were revised and any missing of one questions, the questionnaire were excluded from the analysis.

- Data entry will be carried out using SPSS program version 19.

\section{Statistical analysis:}

The data will be statistically managed by the following tests of significance as appropriate: chi-squared test were used for about all the variables which are quantitative variables. $\mathrm{P} \leq .0 .05$ will be the significance level.

\section{Results: -}

Table 1 shows Comparison between the studied students with and without depression according to the Sociodemographic characteristics which has (sex which is significant with $60 \%$ of those having depression are females compared to $40 \%$ males. Other variables are not significant which are residence, marital status, academic years, living status and part time job)

Table 2 shows Comparison between the studied students with and without depression according to the study situations which has (study years too long and this variable is significant with $60 \%$ of the depressed students were complaining of the long duration of the academic medical years. The variable study units too much is significant with $70 \%$ of students complaining of the quantity of study units that they receive a term. Another significant variable is the amount of information is too much with $90 \%$ of student's agreement. History of failure in exams is also another significant variable in table 2 with $77 \%$ of depressed students don't have history of failure. Other variables are not significant which are teachers have negative effect, acceptance of weekly exams, acceptance of 
exams`results)

Table 3 shows Comparison between the studied students with and without depression according to the medical disorders, substance addiction and stress which has (major stress events variable is significant with 64\% of depressed students are complaining of that. The variable daily stress is significant with $66 \%$ of depressed students suffer from daily stress issues. That variables chronic diseases, chronic medications, smoking and addiction to something are not significant).

Table 4 shows Comparison between the studied students with and without depression according to their satisfaction which has (the variable satisfied with tradition) with $44.9 \%$ of the depressed students are satisfied with their traditions. A significant variable with $63 \%$ of the depressed students are satisfied with their social relations. Satisfied with economic status is a significant variable with $77 \%$ of depressed student are satisfied with their economic status. The variable not satisfied with marriage delay is significant with $57 \%$ of the depressed students were satisfied with the delay of marriage. Other variables are not significant which are satisfied with sleeping hours and satisfied with your weight) These 4 main categories will be described in 4 tables individually.

\section{Corresponding Author: - Abdulrahman Alraddadi}

Address: - Taibah University, Al-Medina, KSA 


\begin{tabular}{|l|c|c|c|c|c|}
\hline \multirow{2}{*}{ Characteristic } & \multicolumn{3}{|c|}{$\begin{array}{c}\text { Normal } \\
\text { N=236 }\end{array}$} & \multicolumn{2}{c|}{$\begin{array}{c}\text { Depression } \\
\text { N=98 }\end{array}$} \\
\cline { 2 - 5 } & NO & \% & NO & \% value \\
\hline Sex & & & & & \\
Male & 127 & 53.8 & 40 & 40.8 & \multirow{2}{*}{$0.03 *$} \\
Female & 109 & 46.2 & 58 & 59.2 & 0.55 \\
\hline Residence & 221 & 93.6 & 90 & 91.8 & \\
Urban & 15 & 6.4 & 8 & 8.2 & \multirow{2}{*}{0.25} \\
Rural & & & & & \\
\hline Marital status & 227 & 96.2 & 92 & 93.9 & \\
Single & 9 & 3.8 & 5 & 5.1 & \multirow{2}{*}{0.64} \\
Married & 0 & 0 & 1 & 1 & \\
Divorced & & & & & \\
\hline Academic year & 54 & 22.9 & 26 & 26.5 & \\
1st & 43 & 18.8 & 22 & 22.4 & \\
2nd & 49 & 20.8 & 16 & 16.3 & \\
3rd & 46 & 19.5 & 20 & 20.4 & \\
4th & 44 & 18.6 & 14 & 14.3 & \\
5th & & & & & \\
\hline Living status & 226 & 95.8 & 89 & 90.8 & \\
With family & 10 & 4.2 & 9 & 9.2 & \\
Away from family & & & & & \\
\hline Another work & 14 & 5.9 & 9 & 9.2 & \\
Yes & 219 & 92.8 & 88 & 89.8 & \\
No & 3 & 1.3 & 1 & 1 & \\
Don`t know & & & & & \\
\hline
\end{tabular}

Table 1:-Comparison between the studied students with and without depression according to the Socio-demographic characteristics.

-* means that there is significance 


\begin{tabular}{|c|c|c|c|c|c|}
\hline \multirow[t]{2}{*}{ Characteristic } & \multicolumn{2}{|c|}{$\begin{array}{c}\text { Normal } \\
\mathrm{N}=236\end{array}$} & \multicolumn{2}{|c|}{$\begin{array}{c}\text { Depression } \\
\mathbf{N}=98\end{array}$} & \multirow[b]{2}{*}{$P$ value } \\
\hline & NO & $\%$ & NO & $\%$ & \\
\hline $\begin{array}{l}\text { Study years too long } \\
\text { Yes } \\
\text { No } \\
\text { Do not know }\end{array}$ & $\begin{array}{c}86 \\
136 \\
14\end{array}$ & $\begin{array}{c}36.4 \\
75.6 \\
5.9\end{array}$ & $\begin{array}{c}60 \\
31 \\
7\end{array}$ & $\begin{array}{c}61.2 \\
31.6 \\
7.1\end{array}$ & $0.00 *$ \\
\hline $\begin{array}{l}\text { Study units too much } \\
\text { Yes } \\
\text { No } \\
\text { Do not know }\end{array}$ & $\begin{array}{c}164 \\
60 \\
12\end{array}$ & $\begin{array}{c}69.5 \\
25.4 \\
5.1\end{array}$ & $\begin{array}{l}69 \\
15 \\
14\end{array}$ & $\begin{array}{l}70.4 \\
15.3 \\
14.3\end{array}$ & $0.00 *$ \\
\hline $\begin{array}{l}\text { Amount of information too much } \\
\text { Yes } \\
\text { No } \\
\text { Do not know }\end{array}$ & $\begin{array}{c}189 \\
37 \\
10\end{array}$ & $\begin{array}{c}80.1 \\
15.7 \\
4.2\end{array}$ & $\begin{array}{c}89 \\
7 \\
2\end{array}$ & $\begin{array}{c}90.8 \\
7.1 \\
2\end{array}$ & $0.05 *$ \\
\hline $\begin{array}{l}\text { Teachers have negative effect } \\
\text { Yes } \\
\text { No } \\
\text { Do not know }\end{array}$ & $\begin{array}{c}142 \\
79 \\
15\end{array}$ & $\begin{array}{c}60.2 \\
33.5 \\
6.4\end{array}$ & $\begin{array}{c}68 \\
21 \\
9\end{array}$ & $\begin{array}{c}69.4 \\
21.4 \\
9.2\end{array}$ & 0.08 \\
\hline $\begin{array}{l}\text { Accept weekly exams } \\
\text { Yes } \\
\text { No } \\
\text { Do not know }\end{array}$ & $\begin{array}{c}117 \\
90 \\
29\end{array}$ & $\begin{array}{l}49.6 \\
38.1 \\
12.3\end{array}$ & $\begin{array}{l}60 \\
25 \\
13\end{array}$ & $\begin{array}{l}61.2 \\
25.5 \\
13.3\end{array}$ & 0.08 \\
\hline $\begin{array}{l}\text { Accept Exams results } \\
\text { Yes } \\
\text { No } \\
\text { Do not know }\end{array}$ & $\begin{array}{l}98 \\
98 \\
40\end{array}$ & $\begin{array}{c}41.5 \\
41.5 \\
17\end{array}$ & $\begin{array}{l}27 \\
54 \\
17\end{array}$ & $\begin{array}{l}27.6 \\
55.1 \\
17.3\end{array}$ & 0.07 \\
\hline $\begin{array}{l}\text { History of failure in exams } \\
\text { Yes } \\
\text { No } \\
\text { Do not know } \\
\end{array}$ & $\begin{array}{c}24 \\
8 \\
204\end{array}$ & $\begin{array}{c}10.2 \\
3.4 \\
86.4\end{array}$ & $\begin{array}{c}20 \\
2 \\
76\end{array}$ & $\begin{array}{c}20.4 \\
2 \\
77.6\end{array}$ & $0.03 *$ \\
\hline
\end{tabular}

Table 2: -Comparison between the studied students with and without depression according to the study situations. means that there is significance 


\begin{tabular}{|c|c|c|c|c|c|}
\hline \multirow[t]{2}{*}{ Characteristic } & \multicolumn{2}{|c|}{$\begin{array}{c}\text { Normal } \\
\mathrm{N}=236\end{array}$} & \multicolumn{2}{|c|}{$\begin{array}{c}\text { Depression } \\
\mathbf{N}=98\end{array}$} & \multirow[t]{2}{*}{ P value } \\
\hline & NO & $\%$ & NO & $\%$ & \\
\hline $\begin{array}{l}\text { Chronic diseases } \\
\text { Yes } \\
\text { No } \\
\text { Don`t know }\end{array}$ & $\begin{array}{c}27 \\
206 \\
3\end{array}$ & $\begin{array}{c}11.4 \\
87.3 \\
1.3\end{array}$ & $\begin{array}{c}17 \\
77 \\
4\end{array}$ & $\begin{array}{c}17.3 \\
78.6 \\
4.1\end{array}$ & 0.07 \\
\hline $\begin{array}{l}\text { Chronic medications } \\
\text { Yes } \\
\text { No } \\
\text { Don`t know }\end{array}$ & $\begin{array}{c}17 \\
217 \\
2\end{array}$ & $\begin{array}{c}7.2 \\
91.9 \\
0.8\end{array}$ & $\begin{array}{c}12 \\
85 \\
1\end{array}$ & $\begin{array}{c}12.2 \\
86.7 \\
1\end{array}$ & 0.3 \\
\hline $\begin{array}{l}\text { Smoking } \\
\text { Yes } \\
\text { No } \\
\text { Don`t know }\end{array}$ & $\begin{array}{c}23 \\
212 \\
1\end{array}$ & $\begin{array}{c}9.7 \\
89.8 \\
0.4\end{array}$ & $\begin{array}{c}9 \\
89 \\
0\end{array}$ & $\begin{array}{c}9.2 \\
90.8 \\
0\end{array}$ & 0.8 \\
\hline $\begin{array}{l}\text { Addiction to something } \\
\text { Yes } \\
\text { No } \\
\text { Don't know }\end{array}$ & $\begin{array}{c}101 \\
129 \\
6\end{array}$ & $\begin{array}{c}42.8 \\
54.7 \\
2.5\end{array}$ & $\begin{array}{c}50 \\
43 \\
5\end{array}$ & $\begin{array}{c}51 \\
43.9 \\
5.1\end{array}$ & 0.1 \\
\hline $\begin{array}{l}\text { Major stress events } \\
\text { Yes } \\
\text { No } \\
\text { Don`t know }\end{array}$ & $\begin{array}{c}112 \\
109 \\
15\end{array}$ & $\begin{array}{c}47.5 \\
46.2 \\
6.4\end{array}$ & $\begin{array}{c}63 \\
31 \\
4\end{array}$ & $\begin{array}{c}64.3 \\
31.6 \\
4.1\end{array}$ & $0.02 *$ \\
\hline $\begin{array}{l}\text { Daily stress } \\
\text { Yes } \\
\text { No } \\
\text { Don`t know }\end{array}$ & $\begin{array}{c}115 \\
110 \\
11\end{array}$ & $\begin{array}{c}48.7 \\
46.6 \\
4.7\end{array}$ & $\begin{array}{l}65 \\
22 \\
11\end{array}$ & $\begin{array}{l}66.3 \\
22.4 \\
11.2\end{array}$ & $0.00 *$ \\
\hline
\end{tabular}

Table 3: -comparison between the studied students with and without depression according to the medical disorders, substance addiction and stress.

means that there is significance 


\begin{tabular}{|c|c|c|c|c|c|}
\hline \multirow{2}{*}{ Characteristic } & \multicolumn{2}{|c|}{$\begin{array}{c}\text { Normal } \\
\mathrm{N}=236\end{array}$} & \multicolumn{2}{|c|}{$\begin{array}{c}\text { Depression } \\
\quad \mathbf{N}=98\end{array}$} & \multirow[t]{2}{*}{$P$ value } \\
\hline & NO & $\%$ & NO & $\%$ & \\
\hline $\begin{array}{l}\text { Satisfied with traditions } \\
\text { Yes } \\
\text { No } \\
\text { Do not know }\end{array}$ & $\begin{array}{c}146 \\
76 \\
14\end{array}$ & $\begin{array}{c}61.9 \\
32.2 \\
5.9\end{array}$ & $\begin{array}{c}44 \\
46 \\
8\end{array}$ & $\begin{array}{c}44.9 \\
46.9 \\
8.2\end{array}$ & $0.01 *$ \\
\hline $\begin{array}{l}\text { Satisfied with social relations } \\
\text { Yes } \\
\text { No } \\
\text { Do not know }\end{array}$ & $\begin{array}{c}182 \\
37 \\
17\end{array}$ & $\begin{array}{c}77.1 \\
15.7 \\
7.2\end{array}$ & $\begin{array}{c}62 \\
31 \\
5\end{array}$ & $\begin{array}{c}63.3 \\
31.6 \\
5.1\end{array}$ & $0.00 *$ \\
\hline $\begin{array}{l}\text { Satisfied with economic status } \\
\text { Yes } \\
\text { No } \\
\text { Do not know }\end{array}$ & $\begin{array}{c}207 \\
26 \\
3\end{array}$ & $\begin{array}{c}87.7 \\
11 \\
1.3\end{array}$ & $\begin{array}{c}76 \\
17 \\
5\end{array}$ & $\begin{array}{c}77.6 \\
17.3 \\
5.1\end{array}$ & $0.02 *$ \\
\hline $\begin{array}{l}\text { Not Satisfied with marriage delay } \\
\text { Yes } \\
\text { No } \\
\text { Do not know }\end{array}$ & $\begin{array}{c}68 \\
153 \\
15\end{array}$ & $\begin{array}{c}28.8 \\
64.8 \\
6.4\end{array}$ & $\begin{array}{l}28 \\
65 \\
14\end{array}$ & $\begin{array}{l}28.6 \\
57.1 \\
14.3\end{array}$ & $0.05 *$ \\
\hline $\begin{array}{l}\text { Satisfied with sleeping hours } \\
\text { Yes } \\
\text { No } \\
\text { Do not know }\end{array}$ & $\begin{array}{c}109 \\
121 \\
6\end{array}$ & $\begin{array}{c}46.2 \\
51.3 \\
2.5\end{array}$ & $\begin{array}{c}34 \\
60 \\
4\end{array}$ & $\begin{array}{c}34.7 \\
61.2 \\
4.1\end{array}$ & 0.1 \\
\hline $\begin{array}{l}\text { Satisfied with your weight } \\
\text { Yes } \\
\text { No } \\
\text { Do not know }\end{array}$ & $\begin{array}{c}128 \\
93 \\
15\end{array}$ & $\begin{array}{c}54.2 \\
39.4 \\
6.4\end{array}$ & $\begin{array}{c}48 \\
44 \\
6\end{array}$ & $\begin{array}{c}49 \\
44.9 \\
6.1\end{array}$ & 0.6 \\
\hline
\end{tabular}

Table 4: -Comparison between the studied students with and without depression according to their satisfaction. means that there is significance 


\section{Discussion: -}

This study is the first one encountered on depression among all the medical students in Taibah University. The present study revealed the prevalence of depression in the studied students to be $29.341 \%$. A close prevalence of depression in Jeddah also reported with prevalence of 14\%-13-and that may go with the similar region and culture. In other studies, in different countries show $10.4 \%$ in USA-6-, $44.8 \%$ in Pakistan-9- and India with prevalence of $49.1 \%-8$-and this might be interrupted by the variation in college's rules and facilities. Medical students of all grades were included in these studies, and their estimated prevalence included common symptoms of depression. High prevalence rate was observed in Pakistan and India-8-9-. The prevalence of depression in our study among medical students is lower than the study of Al-Qassem university with prevalence of 50.3\%-12-. One important possible reason could be that the data was collected in period before AL hajj vacation which is a non-stressful period.

There was significant association between gender and depression in our study with $(\mathrm{p}=0.03)$ shows that females are significantly more depressed than males as in other studies among medical students like in Wah Medical collage with $(\mathrm{p}=0.016)$-22-. This was almost equivalent to depression among a study in Malaysia shows a significant relation between gender $(\mathrm{p}=0.03)$-23-. In our study it was found that the students are satisfied about their relationships ' with others with $(\mathrm{p}=0.00)$ which goes along with A study in Malaysia with $(\mathrm{p}=0.00)-23-$.

These findings are consistent with existing data that our hypothesis was "There is a negative relationship between depression and going through medical levels" but the result was against the expectation which was insignificant with $(\mathrm{p}=0.64)$. This goes along with Wah Medical collage study with $(\mathrm{p}=0.215)-22-$.

Regarding other significant variables like (major stress events and monthly income) with $(\mathrm{p}=0,02$ and $\mathrm{p}=0,02$ ) respectively but insignificant in other studies like Wah Medical collage with $(\mathrm{p}=0.210$ and $\mathrm{p}=0.905)$ respictivly-22-. this difference might be due to free colleges in KSA and good family income while the situation is different in Pakistan. At the same time Pakistan is considered as poor country. However major stress events are significant in our study and that might be because of most of the medical students in Taibah University live with their families and significantly satisfied about their income. So they weren't raised in a tough environment and don't have sense of independency so medical and daily stressful events are considered as unsolved problems for them while students who were raised in different cultures, poor income or live away from their families are different.

\section{Limitations of the study: -}

This survey is the first of its kind in Taibahuniversity. Because of the study was a cross-sectional study, cause-andeffect relationships could not be determined \&The study only comprised medical students from TaibahUniversity, Al-Madinah Al-Monawwara,. Saudi Arabia, and this sample may not necessarily be representative of all medical students in Saudi Arabia. One more limitation with anonymous self-reported questionnaires is inaccurate reporting.

\section{Conclusion: -}

Medical students encountered high rates of depression compared to others. Academic problems and major life events were the main predictors. Enhancing faculty preventive \& curative mental health services is recommended. We recommend case-control studies to determine the risk factors.

\section{Acknowledgement:-}

Author is highly thankfull to Husain Alraddadi, Abdulrahman Aaldaher, Ahmed Alsharef, Rayan alqryqn, Hatem Habeb, Ibrahem Sondokgy, Shahad Abu-Alnasr, Mervat Albejawy, Hind Alnuman, Reyam Alruhaili 


\section{References:-}

1. Cohen JS, Patten S. Well-being in residency training: a survey examining resident physician satisfaction both within and outside of residency training and mental health in Alberta. BMC Med Educ 2005; 5:1-11.

2. www.who.imt/topics/depression/en . health topics - depression

3. Beck,A.T,1967,Depression: Clinical, experimental,and theoretical aspects,xiii, Philadelphia: University of Pennsylvania Press.

4. www.who.imt/mediacentere/factsheets/fs369/en/index.html

5. WHO,2011,National Depression Screening DayTA Curran1, E Gawley1, P Casey2, M Gill1, N Crumlish1,2009,Irish medical journal (impact factor: 0.51),Depression, Suicidality and Alcohol Abuse among Medical and Business Students,09/2009; 102(8,249-52)

6. Liselotte N. Dyrbye, MD, Matthew R. Thomas, MD, and Tait D. Shanafelt, MD,2006,Systematic Review of Depression, Anxiety,and Other Indicators of Psychological Distress journal.Among U.S. and Canadian Medical Students.Acad,Med ,2006; 81,354-373

7. Dr. Ajit Singh,2010,Prevalence of Depression Among Medical Students of a Private Medical College in India,Online,2010;9(4):8

8. Kumar GS, Jain A, Hegde S,2012,Prevalence of depression and its associated factors using Beck Depression Inventory among students of a medical college in Karnataka,Indian ,Journal of Psychiatry,2012 Jul;54(3),223-6

9. S .N. B. Inam, Saqib, E.Alam ,2008,Prevalence of Anxiety and Depression among Medical Students of Private University,Journal of Pakistan,MedicalAssociation,January, 2008

10. Basnet B, Jaiswal M, Adhikari B, Shyangwa PM,2012, Depression Among Undergraduate Medical Students,"In Nepal",Kathmandu,Univ. med,2012;39(3),56-59

11. SN.BazmiInam,Anxiety and deprssion among medical college in saudiarebia, Int.J.Health.Sci (Qassim),v.1(2) : Jul 2007,295-300

12. Nahla IBRAHIM 1, 2, Dania AL- KHARBOUSH 3, Lamis EL-KHATIB 3, Ahd AL -HABIB 3, Dana ASALI 3,2013,Prevalence and Predictors of Anxiety and Depression among Female Medical Students in King Abdulaziz University, Jeddah, Saudi Arabia,Iranian J PublHealth,Vol. 42, No.7, July 2013,pp.726-736

13. Martin.http://psychcentral.com/lib/what-are-the-risk-factors-for depression/000515.

14. Kjeldstadli K, Tyssen R, Finset A, Hem E, Gude T, Gronvold NT, et al. Life satisfaction and resilience in medical school-a six-year longitudinal, nationwide and comparative study. BMC Med Educ 2006; 6:48.

15. Dahlin ME, Runeson B. Burnout and psychiatric morbidity among medical students entering clinical training: a three year prospective questionnaire and interview-based study. BMC Med Educ 2007; 7:6.

16. Tooth D, Tonge K, McManus IC. Anxiety and study methods in preclinical students: causal relation to examination performance. Med Educ 1989; 23:416-21.

17. Warren VJ, Wakeford RE. Do medical students get what they expect? A study of possible mismatch between the expectations and experience of medical education and practice. Med Educ 1990; 24:178-80

18. Hôtel-Dieu de France, Prevalence of anxiety and depressive disorders in medical students. Transversal study in medical students in the Saint-Joseph University of Beirut, 2006 Nov-Dec, PubMed

19. JIM HAGGERTY, 2006, Risk Factors for Depression, http://psychcentral.com

20. The University of Maryland Medical Center, 2013, depression ,http://umm.edu/health/medical/reports/articles/depression.

21. Martin, B , 2006 , What are the Risk Factors for Depression?, http://psychcentral.com/lib/what-are-the-riskfactors-for-depression/000515

22. www.psy.unsw.edu.au/groups, Lovibond, S.H. \&Lovibond, P.f. (1995). Manual for the Depression anxiety Stress Scales. (2nd Ed) Sydney: Psychology Foundation.

23. AlviT,AssadF,RamzanM,Kham FA. Depression,anxiety and their associated factors among medical students. J Coll physicians Surg Pak 2010:20(2):122-126)

24. Mohamad yosef , ahmadabulrahim, mohdyacop. The prevalence of final year medical students with depression symptoms and its contributing factors. International medical journal 2011;18(4):305-309. 